\title{
Auditor objectivity as a function of auditor negotiation self-efficacy beliefs
}

\author{
Jan Svanberg ${ }^{\mathrm{a}}$, Peter Öhman ${ }^{\mathrm{b}}$, Presha E. Neidermeyer ${ }^{\mathrm{c}, *}$ \\ ${ }^{a}$ University of Gävle, Högskolan i Gävle, 80176 Gävle, Sweden \\ ${ }^{\mathrm{b}}$ Mid Sweden University, Department of Business, Economics and Law, Centre for Research on Economic Relations, SE-851 70 Sundsvall, Sweden \\ ${ }^{c}$ West Virginia University, Department of Accounting, PO Box 6025, 1601 University Avenue, Morgantown, WV 26506-6025, USA
}

\section{A R T I C L E I N F O}

\section{Keywords:}

Auditor objectivity

Negotiation self-efficacy

Client identification

Professional identification

Short-tenure threats

\begin{abstract}
A B S T R A C T
This study empirically examines whether an auditor's perceived ability to negotiate discretionary accounting issues with clients (auditor negotiation self-efficacy) is related to auditor objectivity, and whether an auditor's negotiation self-efficacy has a greater impact on her objectivity when the auditor's accuracy motive (professional identity) is strong rather than weak. We tested the hypotheses using a cross-sectional survey design and obtained 146 responses from among 800 surveyed experienced Swedish auditors. The findings indicate that auditors with higher negotiation self-efficacy were more likely to make decisions on a material and discretionary accounting issue contrary to their clients' desires compared to auditors with lower self-efficacy. The relationship between negotiation self-efficacy and auditor objectivity was not moderated by professional-identity strength. These research findings suggest that recruiting and training auditors to increase their negotiation self-efficacy may be an effective method to enhance auditor objectivity without the problems inherent in other methods, such as auditor rotation. Our sample was obtained in Sweden, which allows long auditor tenures. We caution that, although our analysis controlled for auditor tenure, the effect of auditor negotiation self-efficacy may not be generalizable to countries that limit tenure through regulation.
\end{abstract}

\section{Introduction}

This study investigates whether auditor negotiation self-efficacy predicts individual-level outcomes of auditors exercising discretionary judgements in a domain-level negotiation self-efficacy concept (cf. Miles \& Maurer, 2012). Some researchers argue that financial statements are the result of a negotiation between auditors and the client firm's management (Antle \& Nalebuff, 1991; DeAngelo, 1981; Wright \& Wright, 1997). Since auditors desire an accurate audit outcome, they must be able to successfully negotiate with their clients to obtain their desired financial position in a contested situation (McCracken, Salterio, \& Gibbins, 2008). Research suggests that, in an effort to manage the audit's outcome, clients may seek to control the audit process from the beginning (Hellman, 2011), and that this influence over the auditors is higher for more experienced, as compared to less experienced, internal managers (Sweeney \& Pierce, 2011). Prior studies have investigated the negotiation tactics used (Bame-Aldred \& Kida, 2007; Gibbins, McCracken, \& Salterio, 2010; Svanberg, Öhman, \& Neidermeyer, 2018), and the factors determining the outcome of the negotiations (Perreault, Kida, \& Piercey, 2017).

Given that the joint product of the auditor-client negotiation is the external audit and that the accompanying financial statements require consensus decisions, it is important for each party to be able to convince the other of the truth and fairness of its own preferred resolution of a discretionary accounting issue. The auditor's ability to remain faithful to a view informed by the auditor's objective judgment may depend on the perceived ability of the auditor to justify that view, despite knowledge that the client may have convincing arguments for the opposite position. If the auditor does not believe the argument can be won, auditor objectivity is threatened, since the auditor may be more likely to accept the client's point of view. Convincing the client might seem difficult at times, especially bearing in mind that the client's accounting experts will argue against the adjustment (Beattie, Fearnley, \& Brandt, 2001; Gibbins et al., 2010). This paper argues that an auditor's individual confidence in the auditor's ability to successfully contend with clients about discretionary accounting issues impacts the extent to which the auditor may form an objective opinion outside the client's sphere of influence.

We conceptualize this aspect of the auditor's self-confidence using the concept of "auditor negotiation self-efficacy", which is the auditor's perceived ability to successfully negotiate material accounting issues with clients, and examine the extent to which an auditor's perceived ability to successfully negotiate material accounting issues with clients increases the auditor's objectivity in assessing discretionary accounting

\footnotetext{
* Corresponding author.

E-mail addresses: Jan.Svanberg@hig.se (J. Svanberg), Peter.Ohman@miun.se (P. Öhman), Presha.Neidermeyer@mail.wvu.edu (P.E. Neidermeyer).
} 
issues. Auditor negotiation self-efficacy may serve as a barrier to objectivity threats such as financial incentives (e.g., Kadous, Kennedy, \& Peecher, 2003) and non-financial incentives like auditor-client identification (e.g., Bamber \& Iyer, 2007) and client leadership (Svanberg, Öhman, \& Neidermeyer, 2017). This mitigation would occur in situations in which the auditor has a directional motive (e.g., financial gain) as opposed to the accuracy motive associated with the auditor's professional identity (cf. Bauer, 2014; Cianci \& Bierstaker, 2009). Given that high negotiation self-efficacy could encourage auditors to adopt assessments in accordance with the accuracy goal, the present study also examines whether auditors' accuracy motive moderates the impact of auditors' negotiation self-efficacy on auditor objectivity. We anticipate that auditor objectivity does not depend on auditors' negotiation self-efficacy when the accuracy motive is very strong because a strong and salient professional identity is effective protection against lenient auditing (Bauer, 2014), but we anticipate a positive relationship between auditors' negotiation self-efficacy and auditor objectivity for weak and moderate accuracy motives. While prior studies of auditor objectivity have focused largely on the idea that the auditors' judgment is biased as a result of incentives, our analysis investigates the phase that transforms auditor motivation into action. This approach resembles the one described by Wright and Wright (1997) in trying to understand objectivity. They discuss the difference between detecting a misstatement and reporting it, and note that prior studies had addressed the ability to detect misstatements (judgment bias) but not the propensity to report it (potentially depending on relevant self-efficacy).

Our hypotheses are developed from the literature demonstrating how self-efficacy impacts behaviour. This literature defines self-efficacy as "a belief in one's capabilities to organize and execute the courses of action required to produce given attainments" (Bandura, 1997, p. 3), and finds that individuals are unlikely to act or persevere if they do not believe that their actions will have the desired outcomes (Chen \& Bliese, 2002; Stajkovic \& Luthans, 1998). The more successful that individuals believe they can be, the more ambitious are their goals with regard to a given activity (Locke, Frederick, Lee, \& Bobko, 1984; Merchant, 2006). Self-efficacy thus helps determine the goals that an individual will pursue and the amount of goal attainment expected (Locke \& Latham, 1990); it serves above all as a catalyst for the conversion of motivation to action, with familiar actions being more likely, ceteris paribus. The impact of self-efficacy on decisions and behaviour has been consistently evidenced in many areas (Bandura, 1977; Bouffard-Bouchard, 1990; Chen \& Tutwiler, 2017; Phillips \& Gully, 1997; Stajkovic \& Luthans, 1998), including accounting education (Ahmad, Ismail, \& Anantharaman, 2015; Schleifer \& Dull, 2009) and auditing (Iskandar, Sari, Mohd-Sanusi, \& Anugerah, 2012). However, the concept has not been used in research on auditor objectivity. Given that decisions motivated by a desire for accuracy would require that auditors have confidence in their ability to defend their opinions against possible client objections, the context of an auditor's decision-making environment may be viewed as a negotiation (McCracken et al., 2008), with the auditor anticipating a need to defend her position. Accordingly, negotiation self-efficacy would be a relevant concept in the audit context. The negotiation literature provides a foundation for exploring the likely impact of negotiation self-efficacy on decision objectivity, i.e., how selfefficacy affects both the negotiator's approach and the negotiation outcome (cf. Sullivan, O'Connor, \& Burris, 2006).

We test the developed hypotheses using a cross-sectional design employing a survey asking auditors first to assess their individual auditor negotiation self-efficacy and subsequently to make a decision about a case describing a material accounting issue involving their largest client. Auditor objectivity is measured as the extent to which the auditor's decision about the case expresses a concession to the client's desired accounting treatment. We then study the association between perceived auditor negotiation self-efficacy and auditors' concessions to client requirements, while controlling for several variables known from previous studies to affect auditor objectivity.
Our results find a positive relationship between auditor negotiation self-efficacy and objectivity, which is important for two reasons. First, the examination extends the accounting literature by establishing a link between motivation and assessment. Previous research on auditor objectivity has focused on the existence of motives while not addressing other factors that could link motivation to action. In particular, research using archival data to investigate the impact of financial incentives on auditor objectivity (e.g., Dart, 2011; Hackenbrack \& Nelson, 1996) neglects self-efficacy in the transformation of motivation into action.

Second, our main finding, that auditors with high negotiation selfefficacy are more objective than are their peers, adds to the research describing methods to enhance auditor objectivity. In comparison with traditional methods of enhancing objectivity, the strengthening of negotiation self-efficacy would offer two benefits. One is that the impact of negotiation self-efficacy does not require auditors to be aware of how threats to objectivity affect their assessments of accounting issues. Methods that do require auditors to be aware of such threats and to take appropriate action in response may be inadequate because objectivity threats subconsciously bias auditor cognition (Cianci \& Bierstaker, 2009; Svanberg \& Öhman, 2015), rendering traditional methods of decreasing these threats (e.g., auditor rotation or stepping down from an audit assignment) potentially ineffective. A second is that ensuring high negotiation self-efficacy can counteract short-tenure objectivity threats, which is impossible with auditor rotation. This is important given the many threats that arise quickly, potentially after only a few interactions (Bauer, 2014). Audit firms can use reinforcement of auditor negotiation self-efficacy to counter short-tenure threats since self-efficacy can be enhanced by methods under their control (cf. Bandura, 1997), e.g., by appropriate recruitment and/or training (Miles \& Maurer, 2012; Sullivan et al., 2006), or through role modelling of the leadership in the organization in which the person works (Conger \& Kanungo, 1987; Shamir, House, \& Arthur, 1993; Van Knippenberg et al., 2004).

\section{Theory and hypothesis development}

\subsection{Threats to auditor objectivity}

Research on auditor objectivity seldom discusses the psychological processes through which an auditor's judgment is biased by perceived directional motives. According to our review of the literature, there are only a few attempts to discuss the psychological processes, and these are based on motivated reasoning theory (Kunda, 1990). The accounting literature has examined two types of threats to auditor objectivity: the extent to which financial factors (e.g., Hollingsworth \& Li, 2012; Kadous et al., 2003) and non-financial or social factors (Bamber \& Iyer, 2007; Stefaniak, Houston, \& Cornell, 2012; Bauer, 2014; Svanberg \& Öhman, 2015; Svanberg and Öhman, 2016; Svanberg et al., 2017; Svanberg et al., 2018) are associated with constrained auditor objectivity. Unfortunately, the research about financial factors neglects any explicit discussion of the mental processes through which expected financial gains can constrain auditor objectivity. The research on social threats to auditor objectivity discusses explanations of the impact of social forces on auditor objectivity, based largely on motivated reasoning theory, social identity theory, and leadership theory. These studies generally use only the most common control variables, e.g., auditor experience and tenure; self-efficacy for converting motivation to behavior is conspicuously absent. We summarize some of the prior research on auditor objectivity below.

The most frequent approach to auditor objectivity is to investigate the impact of financial incentives. The literature discussing the factors affecting auditor motives assumes that financial incentives motivate auditors' work. For example, in a study of auditors' abilities to adjust their auditing efforts and billing to client earnings-manipulation and corporate governance risk, Bedard and Johnstone (2004) note that auditors should have a motive to account for these risks because they 


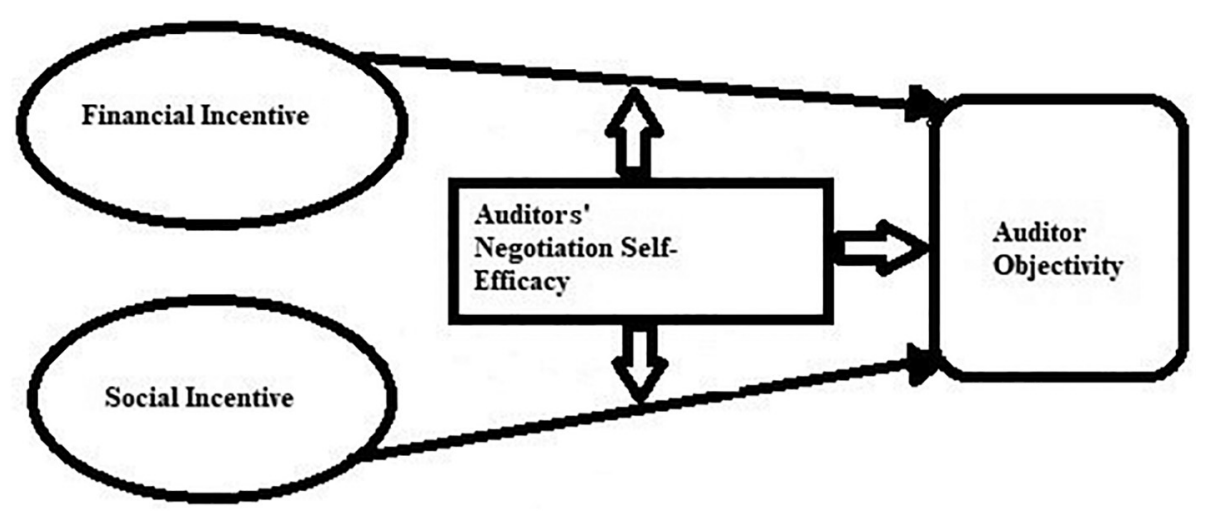

Fig. 1. Objectivity threats and auditors' negotiation self-efficacy.

would want to reduce the chances of litigation or of reputation decline. Hillison and Peecher (2017) takes an alternate tack finding that the financial incentives of a commercial orientation is salient for more senior auditors in which the auditor is concerned with keeping the client's business rather than a stakeholder interest.

One area of study is the effect of Non-Audit Services (NAS) fees on auditor objectivity, given the relatively larger magnitude of NAS fees compared to those of the audit fee (Weil \& Tannenbaum, 2001). This research questions the objectivity of the audit firm and auditors delivering the NAS, given their actual or perceived dependence on the fees provided by the NAS client firm. Despite the fact that most studies indicate that NAS does not impact objectivity (e.g., Ashbaugh, 2004; Callaghan, Parkhash, \& Singhai, 2009; Craswell, Stokes, Donald, \& Laughton, 2002; DeFond, Raghunandan, \& Subramanyam, 2002; Geiger \& Rama, 2003; Simunic, 1984;), NAS is regarded as a threat to auditor objectivity. Some studies indicate a negative effect of NAS on accounting quality (Frankel, Johnson, \& Nelson, 2002; Srinidhi \& Gul, 2007) and auditors' perceived objectivity (Brandon, Crabtree, \& Mayer, 2004; Dykxhoorn \& Sinning, 1982; Francis \& Ke, 2006; Frankel et al., 2002; Krishnan, Samie \& Zhang, 2005; Lavin, 1977; Shockley, 1981). Other studies suggest that client importance, measured as the combination of NAS and audit fees, may compromise auditor objectivity (Francis, 2006; Gul, 1991). The opposite argument is offered by Keune and Johnstone (2012), who find a positive association between audit quality, measured as auditors not allowing managers to waive material misstatements, and audit fees. Auditors protect their reputations when the downside risks are high (Larcker \& Richardson, 2004; Reynolds \& Francis, 2000), and may curtail aggressive client managers more often when audit fees are high (Nelson, Elliott, Tarpley, \& Gibbins, 2002; Sanchez, Agoglia, \& Hatfield, 2007; Trotman, Wright, \& Wright, 2005). The common denominator of all financial threats to auditor objectivity is the anticipated financial gain the auditor discounts by serving a client.

Social threats to auditor objectivity are caused by the auditor-client social relationships. The idea is that auditors might develop too close relationships with clients over time, with auditor or audit-firm tenure a possible risk factor. Whether long tenure improves audit quality or impairs auditor objectivity is debated. Some findings suggest that long tenure is a problem (Carey \& Simnett, 2006; Deis \& Giroux, 1992), while other findings question objectivity impairment (Geiger \& Raghunandan, 2002; Knechel \& Vanstraelen, 2007). The first study of a psychological mechanism as a cause of the relationship problem was conducted by Bamber and Iyer (2007). They found that auditors identify with their largest clients and that client-identification constrains auditor objectivity. This effect was later confirmed by several studies (Bauer, 2014; Stefaniak et al., 2012; Svanberg \& Öhman, 2015). The effect is explained with social identity theory predicting that clientidentified auditors tend to merge psychologically with their clients, taking their clients' interests to heart, so that the auditors become more intrinsically motivated to act in the clients' interests. Regarding tenure, identifying with clients does not require very large clients (Svanberg \& Öhman, 2015) and may occur after only a few client interactions, constituting a short-tenure threat (Bauer, 2014).

A recently discovered social threat is the exercise of client leadership. Svanberg and Öhman (2016) examined whether auditor objectivity is constrained by the leadership exercised by charismatic client chief financial officers (CFO) and found a negative impact of charismatic client leadership on auditor objectivity. In a second study, Svanberg et al. (2017) found a negative impact on auditor objectivity of transformational client leadership, which is the most frequently adopted leadership construct in the leadership literature.

A third potential category of objectivity research is the study of auditing as a negotiation; but such studies have predominantly focused on the auditor's ability to convince the client and not the other way around, e.g. on how the auditor's choice of negotiation approach triggers cooperation or resistance of the client (cf. Perreault \& Kida, 2011; Perreault, Kida, \& David Piercey, 2017), although Gibbins et al. (2010) noted that an auditor's preference for integrative tactics in itself is an objectivity problem. Thus, the negotiation concept has not been used in relation to auditor objectivity.

In the present study, we view auditor objectivity research as focusing on the two types of incentives that threaten the auditor's objective judgment. Prior research incorporates a number of contextual variables, such as auditor experience, in addition to tenure and the two main types of threats to objectivity listed above. Auditor experience increases auditor objectivity (Kaplan, O'Donnell, \& Arel, 2008) because experienced professionals develop effective mental models for interpreting evidence during evaluative judgment tasks (Libby \& Luft, 1993; Patel \& Groen, 1986). Fig. 1 summarizes this discussion omitting the contextual factors.

\subsection{Objectivity bias and the motivation-self-efficacy-performance chain}

When an auditor wants to move towards a specified conclusion, motivated-reasoning theory states that the outcome will be achieved when it can be justified to a dispassionate observer. Self-efficacy could therefore have an effect on auditor objectivity when it affects the likelihood of desiring one outcome over another. We now discuss this possibility.

Directional motivation constrains objective judgment because it triggers an individual's personal memory-search and belief construction. People with directional motivation (i.e., the desire to arrive at a certain outcome) may assess mixed evidence by favouring beliefs consistent with their desired outcome and discounting the inconsistent beliefs. This type of information processing may be caused simply by posing directional questions inducing these people to use a positive test strategy (Klayman \& Ha, 1989), or by a combination of cognitive processes involving memory-search bias and biased-belief construction. 
There is equivocal evidence that directional motivation constrains judgment such as auditor objectivity (Kunda, 1990).

In the absence of strong directional motives, auditors will select the feasible objective path, possibly electing to move towards a specific conclusion in an audit for intrinsic or extrinsic reasons. Financial incentives provide extrinsic motivation, while non-financial incentives provide intrinsic motivation. Auditors may experience conflicting desired outcomes, and a directional motive may be opposed by the accuracy motive associated with professional identity (Suddaby, Gendron, \& Lam, 2009). Competing demands are the normal state for most people in many situations (Cerasoli, Nicklin, \& Ford, 2014). With conflicting motives pulling the auditor in potentially opposite directions, the outcome will depend on the relative strengths of the auditor's motivations to satisfy client demands as compared to those of ensuring accuracy in the auditor's professional obligations. In making this decision, auditors will likely act in the way they feel most confident, as most individuals do (cf. Bandura, 1997). When motivations are the same, the path with high self-efficacy will prevail. This dynamic is crucial to how effectively extrinsic and intrinsic motivations affect people's choices of action. For an auditor, high negotiation self-efficacy would make the accuracy motive a more likely driver of audit judgment even in cases in which financial incentives were strong or there was a strong identification with the client. The effect on auditor objectivity of priming an auditor's professional identity found by Bauer (2014) supports these arguments.

\subsection{Auditor negotiation self-efficacy}

Self-efficacy is a person's own estimate of how well he or she can execute courses of action required to deal with prospective situations. It addresses the relationship between personal ability and behaviour, and refers to beliefs about whether particular behaviours affect outcomes (Bandura, 1982, 1997). Self-efficacy is generally defined with a specific task in mind, but it can also refer to a wide range of achievement situations (Chen, Gully, \& Eden, 2001). The wider-ranging, general concept has been demonstrated to have weak predictive value (Lee and Bobko, 1994), while the specific self-efficacy concept has better predictive value for most types of activities, as long as they are not complex. Given that an individual is more inclined to pursue activities whose outcome will lead to success, the specific self-efficacy beliefs will determine the activities pursued and the subsequent level of personal performance.

Decades of research into self-efficacy indicate its reliability as a predictor of a range of behaviours, with better performance occurring in people with higher self-efficacy (Stajkovic \& Luthans, 1998). People with confidence in their capacity to carry out a specific task anticipate successful performance, focus on how to succeed, and persist in the face of difficulty (Bandura \& Cervone, 1983), while those with low self-efficacy for a task anticipate failure, focus on problems, and react to challenges by reducing their efforts or giving up completely. This diversity is a key to our study (cf. Bandura, 1997), and one possible consequence is that auditors with higher negotiation self-efficacy would tend to make less-lenient discretionary decisions about material accounting issues than would their peers with lower negotiation self-efficacy. Being able to defend an assessment is important, because otherwise if/when the client protests, the ensuing argument would be lost. Auditors' perceptions of their ability to defend their decisions in discussions with clients therefore are crucial to their propensities to make decisions.

The importance of self-efficacy has been reported in many areas of behaviour, and there is evidence it has a positive effect on job performance and other desired outcomes. For example, teachers with high self-efficacy work harder, are more involved in informal learning activities, are more persistent and less stressed than their peers (Lohman, 2006), and perform better in the classroom (Tschannen-Moran, Woolfolk-Hoy, \& Hoy, 1998). As a result, these teachers elicit higher student motivation (Midgley, Feldlaufer, \& Eccles, 1989) and achievement (Caprara, Barbaranelli, Steca, \& Malone, 2006) as a result of their higher teaching self-efficacy. In the audit context, Iskandar, Nelly-Sari, Mohd-Sanusi, and Anugerah (2012) reported that auditors with higher general self-efficacy invest more effort in audit tasks.

Previous studies of the impact of self-efficacy on negotiation have produced somewhat mixed results. Several studies have found positive support for the effect of self-efficacy on negotiation outcomes (Brett, Pinkley, \& Jackofsky, 1996; Gist, Stevens, \& Bavetta, 1991; Miles \& Maurer, 2012; Stevens \& Gist, 1997), while Sullivan et al. (2006) found no support for this effect. This discrepancy may be due to the levels of generality at which self-efficacy is adopted. As mentioned, self-efficacy generally is a spectrum ranging from very specific "task" requirements, through requirements within a specific "domain", to requirements mandatory for "general" interaction. Although a specific self-efficacy concept is preferable (Lee \& Bobco, 1994), Miles and Maurer (2012) claimed that negotiation self-efficacy predicts better negotiation outcomes only when it is a domain-level construct (located in the area of negotiation), but not when it is defined as a task-specific construct (related to a specific negotiated requirement being acted upon). Negotiators may not have a clear view of their ability to negotiate under particular circumstances in a task-specific situation, but they have a better chance of having a clear view of their ability to negotiate in a domain-level context. Task-specific negotiations require that the negotiator not only know about the unique task at hand but also know about the counterparty in the negotiation. Therefore, predicting taskspecific performance in negotiations is more difficult than is predicting performance in less-complex, less-ambiguous tasks (Miles \& Maurer, 2012). These circumstances, and the mixed results of studies of negotiation self-efficacy, suggest that domain-level negotiation self-efficacy is the most suitable level of generality at which to assess negotiation self-efficacy.

In the negotiation-tactics literature there is evidence that the negotiator's choice of negotiation tactic depends on the negotiator's selfefficacy for various tactics (Sullivan et al., 2006), suggesting that relevant self-efficacy beliefs predispose the negotiator to embark on a particular type of negotiation. This indicates that self-efficacy for negotiation affects the likelihood of choosing to negotiate at all, suggesting that insufficient self-efficacy may make an auditor avoid negotiations. Consequently, auditors with low negotiation self-efficacy may avoid decisions that they find difficult to defend. This avoidance is supported by reports in the ethical-behaviour literature that self-efficacy affects ethical behaviour (Youssef \& Luthans, 2005). People with efficacious beliefs regarding their ability to behave ethically are more likely to do so despite facing harsh reactions from other organization members (Miceli \& Near, 1992).

Relevant self-efficacy beliefs make a person likely to pursue courses of action that are uncertain or require persistence. Auditors have to deal with many such situations because they must balance the motivation to maintain good relationships with clients against making objective decisions about client accounting (Carrington, Johansson, Johed, \& Öhman, 2013; Mayhew, Schatzberg, \& Sevcik, 2001; Suddaby et al., 2009). This means that auditors must address their clients in a way that enables auditors to avoid both damaging the client relationship and the potential risk of litigation. If the auditor has high (domain-level) negotiation self-efficacy, we anticipate that the auditor is less likely to acquiesce to the client-preferred accounting position than if the auditor has low (domain-level) negotiation self-efficacy. We formulate this as the following hypothesis:

H1. High auditor domain-level negotiation self-efficacy increases auditor objectivity.

Our argument about negotiation self-efficacy assumes that self-efficacy acts as a moderator of the relationship between motivation and action. In particular, we anticipate that the relationship between the auditor's accuracy motive (cf. Cianci \& Bierstaker, 2009) and objective assessments is moderated by negotiation self-efficacy. However, in our 
study we are primarily interested in whether and how auditor negotiation self-efficacy impacts auditor objectivity, and we therefore examine whether the magnitude of an auditor's accuracy motive moderates the impact of negotiation self-efficacy on her objectivity.

The definition and psychological function of self-efficacy as a transformer of motivation to action suggests that the effect of self-efficacy may vary with the amount of motivation to act. It is apparent that the effect of self-efficacy must depend on whether there is a motivation to act at all (Hwang, Han, \& Chiu, 2015), because if a person has no motivation to act, the belief in her ability to act and succeed should not affect the likelihood of engaging in the act, but if a person has at least some motivation to engage in an act, believing in her ability to do so and succeed should impact the likelihood of acting. Previous research suggests a positive relationship between perceived job autonomy and self-efficacy (Jungert, Hourfort, \& Schattke, 2013; Wang \& Netemeyer, 2002). This is reasonable because the more autonomy a person has, the more discretionary become the decisions that constitute or lead up to behaviour. Self-governed, discretionary decisions should hinge more on the decision-makers perceived ability than on extrinsically motivated, less discretionary decisions.

Thus, moving from a very low-level accuracy motive to an intermediate level should set the potential of the impact of negotiation selfefficacy in motion. Furthermore, accuracy motivation is associated with the professional identity so it is experienced as a moral obligation towards the profession and towards society. Prior evidence demonstrates that professional identification is a strong motivation for auditors if professional identification is strong and if the professional identity is salient (Bauer, 2014). Auditors with a strong professional identity made salient are unlikely to be lenient towards their clients because they feel not only a strong motivation, but also a strong moral obligation to conduct the audit in accordance with objective standards. Even with a weak auditor negotiation self-efficacy, they are unlikely to abandon their assessment and accept a client demand. But auditors who identify on a moderate level with their profession might be more dependent on their auditor negotiation self-efficacy than the high and the very low identifiers, because the moderate identifiers have sufficient identification to perceive a considerable, but not unlimited, obligation towards their profession. Self-efficacy beliefs should come into play mostly for auditors with a moderate to low accuracy motivation, but not at all for auditors with a very low accuracy motivation.

We do not measure the accuracy motive directly, but we do measure the strength of the auditors' professional identity. This identity is an important motive for accuracy on the part of an auditor, particularly when it is made salient (Bamber \& Iyer, 2007; Bauer, 2014; LeBoeuf, Shafir, \& Bayuk, 2010). We therefore anticipate that auditors with weak to moderate professional identities exhibit a stronger impact of auditor negotiation self-efficacy on auditor objectivity than do auditors with strong professional identities. We accordingly formulate this additional hypothesis as follows:

H2. The relationship between negotiation self-efficacy and auditor objectivity is moderated by professional-identity strength.

\section{Method}

\subsection{Sample and data collection}

Using a register from Revisorsinspektionen (the Swedish Supervisory Board of Public Accountants), we selected a random sample of 800 experienced auditors in Sweden and e-mailed them a link to a survey. This approach ensured the anonymity ${ }^{1}$ of the respondents,

\footnotetext{
${ }^{1}$ Convincing respondents that their responses were absolutely anonymous was a key issue because of the risk of social desirability bias that plagues behavioural ethics research (Randall \& Fernandes, 1991) and because of the risk
}

as the survey software did not record their email addresses or names. We obtained 146 responses, representing an 18.3\% response rate, achieved after reminding the respondents four times over three weeks in late 2014.

To ensure against non-response bias in the sample, we employed a method described by Armstrong and Overton (1977) in which late respondents' answers are used as a proxy for non-respondents' answers. We treated any difference between late and early respondents as a measure of non-response bias. Analysing the results using ANOVA, we found no significant differences between the late and early respondents, helping alleviate the concern about non-response bias.

\subsection{Research design and measures}

To collect data for the study, ${ }^{2}$ we asked the respondents to assess his or her domain-level auditor negotiation self-efficacy (cf. Youssef \& Luthans, 2005) and to make a decision about a hypothetical case describing a situation in which the largest client has material unrecorded liabilities. The negotiation involves whether the auditor will pursue his or her position, and enforce the booking of the liability, or instead accept the client's demand, subordinating his or her audit judgment to that of the client management. The extent to which the auditor's decision about the case expresses a concession to the client's desired accounting treatment measures the auditor's objectivity. We then investigated the association between the auditor's perceived domain-level negotiation self-efficacy and the auditor's concession to client requirements. To ensure that we examined the impact of auditor negotiation self-efficacy in an audit context (i.e., the hypothetical case) that involves a discretionary decision and a conflict of opinion between auditor and client, we used measurement instruments and a case that had been tested in previous studies. We also controlled for several previously identified phenomena that may affect auditor objectivity. All measures and items used in the study are presented in the Appendix.

Domain-level auditor negotiation self-efficacy was measured using a rephrased version of the eight-item negotiation self-efficacy measure developed by Sullivan et al. (2006), modified for the domain level by Miles and Maurer (2012) by asking the questions without referring to a particular case, as a measure of an auditor's perceived ability to negotiate his or her standpoint versus the client's. We adjusted the items to fit the audit context. The items contained ten-point Likert scales anchored at "do not agree at all" (1) and "totally agree" (10). Miles and Maurer (2012) used only the four distributive negotiations of the eight total negotiation items described by Sullivan et al. (2006). We used both the distributive and integrative negotiation items from Sullivan et al. (2006). While Sullivan et al. (2006) claim the two types of negotiation tactics represent two factors, Lax and Sebenius (2011) argue that distributive and integrative negotiation are intertwined to such an extent that they cannot be separated. Miles and LaSalle (2008) support the latter interpretation and are unable to explicate two factors. Due to the weak theoretical basis for distinguishing factors, we considered the negotiation self-efficacy items as describing a phenomenon that might consist of one, two, or even several as yet unknown factors. Due to the weak theoretical foundation and this uncertainty, we analysed the auditor negotiation self-efficacy instrument using principal component analysis and found that auditor negotiation self-efficacy items grouped as a one-dimensional construct. The internal reliability (Cronbach's alpha) of the construct was 0.872 , indicating satisfactory internal reliability of the scale viewed as a one-dimensional construct.

The questionnaire contained a short case adapted from earlier research into auditor behaviour in an audit conflict situation (Bamber \&

(footnote continued)

of obtaining low response rates, which is also a problem in survey research.

2 The survey was approved by the University and was pilot tested and revised before distribution. 
Iyer, 2007). Several studies have successfully used this recall method to elicit responses from auditors (e.g., Gibbins, McCracken, \& Salterio, 2005; Gibbins \& Newton, 1994; Svanberg \& Öhman, 2015). Respondents were asked to assume that the case involved their largest client, and the case describes a situation in which the auditor's view is that unrecorded liabilities are material but the client's management strongly disagrees. The respondents were asked about the likelihood that they would accept the client-preferred treatment and not require that the liabilities be recorded in the financial statements, which they indicated on a reverse-scored probability scale running from "very high likelihood" (1) to "very low likelihood" (10), with a lower score representing a higher likelihood that the auditor will give in to the client's requirements.

Because we examined the impact of domain-level auditor negotiation self-efficacy in an environment in which auditors might identify with their clients and/or the audit profession, the survey measured client identification, professional identification, and the impact of these on auditor objectivity. We adopted the measure of client identification and professional identification from the Organizational Identification Scale (Mael \& Ashforth, 1992; Wan-Huggins, Riordan, \& Griffeth, 1998), but used a rephrased version developed by Bamber and Iyer (2007) that has a client orientation and an audit orientation, respectively. The items contained ten-point Likert scales ranging from "do not agree at all" (1) to "totally agree" (10). Using principal component analysis, we ensured that the client-identification items loaded on one component. The internal reliability (Cronbach's alpha) of the clientidentification scale was found to be 0.77 , indicating that the clientidentification items represented a one-dimensional scale with satisfactory internal reliability. The corresponding value for the professionalidentification scale was 0.78 .

The client-importance item, previously used by Bamber and Iyer (2007), was measured using a four-point Likert scale ranging from "not at all important" (1) to "very important" (4). Given that auditors may be affected by financial dependence, we also included such a possibility in our model testing the impact of auditor negotiation self-efficacy. The auditor's financial dependence was measured using the proxy "client size" in terms of the annual turnover (SEK million) of each auditor's largest client. Auditor experience in years and auditor tenure in years were measured using one item each, and we measured the type of audit firm by asking whether or not the auditors were employed in a Big- 4 firm.

\section{Analysis and results}

\subsection{Descriptive statistics}

Demographic information about the respondents is summarized in Table 1. The respondents, most of whom are male, are equally distributed between Big 4 and other audit firms. On average, the respondents are 47.3 years old and have been auditors for approximately 20 years. Their long experience indicates that the sampled auditors are in positions in which contact with client management and decisions on important auditing issues should be relevant. The average length of time that they have audited their largest client is eight years. Our sample of auditors is from Sweden, which does not regulate auditor tenure or audit-firm tenure in the same way as many other countries; therefore our sample tenure is longer than it would be in countries that regulate tenure more rigorously.

Table 1 shows that the auditor negotiation self-efficacy score averages 6.33 , indicating that auditors perceive themselves as relatively skilled at negotiating material accounting issues with client management. The auditors' client-acquiescence score refers to the likelihood that auditors would accept the client-preferred treatment and not require that material liabilities be recorded in the financial statements. As this item is coded and reported in Table 1 , the score corresponds to auditor objectivity. A high score indicates a high probability of not accepting the client management's preferred accounting position, which means a low degree of leniency towards client management, indicating an objective standpoint. The average score of 8.22 indicates that the sampled auditors would frequently require that the liability be recorded. Moreover, the average client identification is 3.68 and the average professional identification is 6.22 . Our values are well in line with those of previous studies (e.g., Bamber \& Iyer, 2007; Svanberg \& Öhman, 2015), so the sampled auditors identify with their clients and with their profession at expected levels.

\subsection{Hypothesis test results}

Table 2 presents Spearman's rank correlation coefficients for the variables. The Spearman's test is a non-parametric technique adopted because the auditors' client-acquiescence score distribution is skewed. The correlations reveal potentially meaningful relationships between several variables. There is a significant negative correlation between self-efficacy and auditors' client acquiescence $(p<0.01)$, indicating preliminary support for H1. There is a positive correlation between client identification and auditors' client acquiescence $(p<0.01)$, confirming previous findings (Bamber \& Iyer, 2007; Stefaniak et al., 2012; Svanberg \& Öhman, 2015). Interestingly, the univariate analysis seems to indicate that there is no relationship between client identification and either of the variables auditor tenure and client size, contrary to social-identity theory predictions (Bamber \& Iyer, 2007). The dichotomous variable Big 4 is correlated with several variables, indicating that Big-4 auditors identify more strongly with clients $(p<0.01)$ and have a stronger professional identity than do other auditors $(p<0.01)$. As expected, Big-4 auditors deal with larger clients $(p<0.01)$.

Age and experience are highly correlated, conveying very similar information. For this reason, only auditor experience is presented in Table 3, with age excluded due to multicollinearity. Similarly, gender was not a significant variable and was thus dropped from the model.

Table 3 presents data from the multiple regressions. Conditions for the suitability of linear regression for the present data were examined including linearity, independent residuals, collinearity, skewness, kurtosis, and normal distribution of residuals. Collinearity statistics were generated to verify whether the relatively high pairwise correlations between the variables client identification, professional identification, auditor tenure, and the variables auditor experience, Big 4, and client size indicate multicollinearity in the regression model. Regarding collinearity statistics, the tolerance values were all below 1 and the variance inflation factor (VIF) values were all between 1.0 and 1.8, suggesting no multicollinearity. We ensured that the residuals were normally distributed by using the Shapiro-Wilk test and by visually examining the diagrams, all of which displayed approximately normal distribution.

H1 was tested using a linear regression model, called model 1 in Table 3 , which is significant $(p<0.001)$. The dependent variable is auditors' client acquiescence, and we are primarily interested in the relationship between auditor negotiation self-efficacy and auditor client acquiescence. The coefficient for auditor negotiation self-efficacy is significant in the model $(p<0.01)$ and the size of the coefficient, 0.412 , suggests a substantial impact of auditor negotiation self-efficacy on auditor objectivity, indicating distinct support for H1. Accordingly, there is a significant relationship between auditors' domain-level negotiation self-efficacy and auditor objectivity, meaning that the higher the perceived negotiation self-efficacy capacity, the higher the degree of objectivity. The interaction between professional identity and auditor negotiation self-efficacy is insignificant $(p>0.1)$, providing no support for $\mathrm{H} 2$ that the effect of negotiation self-efficacy on auditors' client acquiescence is stronger when the auditors' professional identity is stronger.

Moreover, we find that client identification has a strong negative and significant association $(p<0.001)$ with auditor objectivity, with a 
Table 1

Descriptive statistics.

\begin{tabular}{|c|c|c|c|c|c|c|}
\hline Variables & Frequency & Mean & SD & Median & Min & Max \\
\hline Male & 110 & & & & & \\
\hline Female & 36 & & & & & \\
\hline Big 4 & 73 & & & & & \\
\hline Non-Big 4 & 73 & & & & & \\
\hline Age (years) & & 47.33 & 10.55 & 48 & 30 & 74 \\
\hline Experience (years) & & 20.34 & 8.95 & 20 & 5 & 41 \\
\hline Auditor tenure (years) & & 8.12 & 5.23 & 7 & 2 & 25 \\
\hline Client size, sales (SEK million) & & 3183.16 & $14,186.06$ & 200 & 30 & 100,000 \\
\hline Client acquiescence $(1-10)_{*}$ & & 8.22 & 1.83 & 9 & 2 & 10 \\
\hline Auditor negotiation self-efficacy (1-10) & & 6.33 & 1.33 & 7.13 & 2.38 & 10 \\
\hline Client identification (1-10) & & 3.68 & 1.96 & 3.40 & 1 & 9.80 \\
\hline Professional identification (1-10) & & 6.22 & 1.93 & 6.40 & 1 & 10 \\
\hline Client importance (1-4) & & 2.21 & 0.74 & 2 & 1 & 4 \\
\hline
\end{tabular}

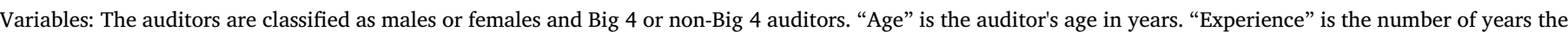

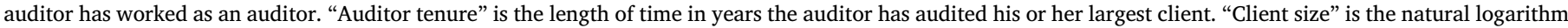
of the largest client's annual turnover in SEK. "Client acquiescence" measures the extent to which an auditor is lenient towards the client-preferred treatment.

* In this table we report the raw data values; for this variable, 10 means not lenient at all (completely objective) and 1 means totally lenient (not objective at all),

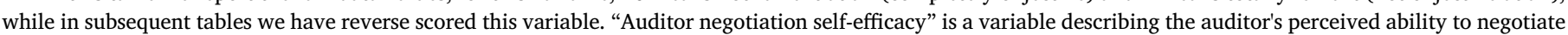

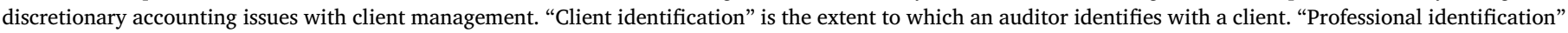

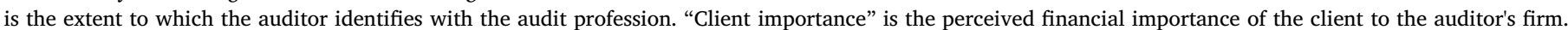

Table 2

Spearman's rank correlations.

\begin{tabular}{|c|c|c|c|c|c|c|c|c|}
\hline Variables & Auditor negotiation self-efficacy & Client iden. & Professional iden. & Client importance & Experience & Auditor tenure & Big 4 & Client size \\
\hline Client acquiescence & $-0.312^{* * *}$ & $0.351^{* * *}$ & $-0.217^{* * * *}$ & 0.101 & -0.001 & -0.031 & 0.074 & 0.148 \\
\hline Auditor negotiation self-efficacy & & 0.078 & $0.243^{* * *}$ & -0.001 & -0.033 & -0.030 & 0.108 & $0.182^{* *}$ \\
\hline Client iden. & & & $0.490 * * *$ & $0.167^{* *}$ & -0.057 & -0.017 & $0.270 * * *$ & 0.053 \\
\hline Professional iden. & & & & 0.056 & -0.003 & -0.135 & $0.340^{* * *}$ & 0.028 \\
\hline Client importance & & & & & 0.110 & 0.059 & -0.071 & $0.194^{* *}$ \\
\hline Experience & & & & & & $0.461^{* * *}$ & -0.129 & -0.029 \\
\hline Auditor tenure & & & & & & & -0.121 & $-0.220 * *$ \\
\hline Big 4 & & & & & & & & $0.422^{* * *}$ \\
\hline
\end{tabular}

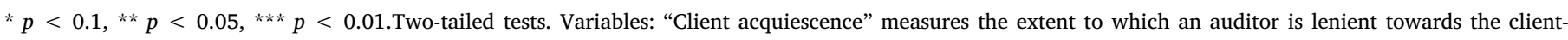

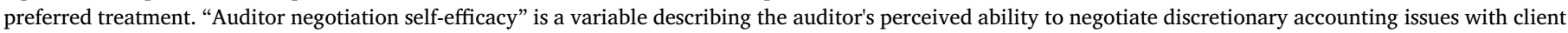

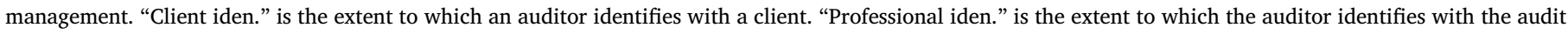

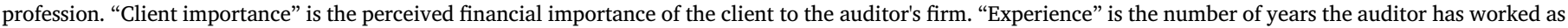

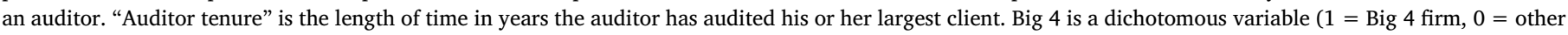
audit firm). "Client size" is the natural logarithm of the largest client's annual turnover in SEK.

high regression coefficient (0.648). This empirical evidence confirms previous findings of Bamber and Iyer (2007), Stefaniak et al. (2012), and Svanberg and Öhman (2015) that client identification impairs objectivity. Contrary to our expectation, we do not find a relationship between auditor professional identification and auditor objectivity $(p>0.1)$. However, the lack of a relationship between these constructs was earlier reported by Svanberg and Öhman (2015), while Bamber and Iyer (2007) reported a weak such relationship.

We do not find a significant relationship between client size and auditor objectivity at the $5 \%$ significance level, but the $p$-value provides some indication at the $10 \%$ level that larger clients pose a greater threat to objectivity than do smaller clients $(p<0.077)$. Moreover, we find no significant difference between Big-4 auditors and other auditors regarding their propensity to acquiesce to the client-preferred treatment. Auditor experience and auditor tenure also appear to have no impact on the likelihood of acquiescing to client preferences. The latter results are somewhat at odds with previous findings, but the present study is the first to analyse these variables included in the same model as auditor negotiation self-efficacy and auditor-client identification. The combination of these variables makes it less clear than it seemed in previous research that auditor experience and auditor tenure have any direct effect on auditor objectivity.

\section{Discussion}

The present study applied a domain-level negotiation self-efficacy concept (cf. Miles \& Maurer, 2012) to auditor-objectivity research in order to assess the ability of auditor negotiation self-efficacy to predict the individual-level outcomes of auditors' exercise of discretionary judgment. Auditor negotiation self-efficacy is an auditor's perceived ability to successfully negotiate a material and discretionary accounting issue with his or her clients, and we anticipated that this perceived ability would influence auditors' judgments because auditors feel they must be able to justify their decisions to their clients. We used selfefficacy as the starting point because there is reason to believe that auditors' objectivity depends not only on their motivation, but also on their self-efficacy beliefs about acting in accordance with those motivations. In particular, we claim that self-efficacy beliefs are important in translating accuracy motives into action, given the potential for client opposition. The directional motives that constrain objectivity encourage auditors to act in accordance with client desires and are not associated with opposing clients who demand justification of auditor judgment. This is an aspect of the motivation-self-efficacy-performance chain that has been overlooked by the previous accounting literature.

We adopted motivated reasoning theory (e.g., Kunda, 1990) and previous evidence from the self-efficacy literature (e.g., Miles \& Maurer, 2012) to develop our hypotheses that there is a positive relationship between domain-level auditor negotiation self-efficacy and auditor 
Table 3

Multiple regression of the effect of auditor negotiation self-efficacy on auditor objectivity.

\begin{tabular}{llll}
\hline Dependent variable & Predicted sign & \multicolumn{2}{l}{ Model 1} \\
\cline { 2 - 4 } & & \multicolumn{2}{l}{ Client acquiescence } \\
\hline Variable & & Coeff. & Sig. \\
Auditor negotiation self-efficacy & - & -0.412 & $0.002^{* *}$ \\
Client identification & + & 0.648 & $0.000^{* * *}$ \\
Professional identification & - & 0.086 & 0.592 \\
Client importance & + & 0.146 & 0.425 \\
Experience & - & 0.005 & 0.745 \\
Auditor tenure & + & -0.021 & 0.485 \\
Big 4 & - & -0.107 & 0.709 \\
Client size & + & 0.140 & $0.077^{*}$ \\
Professional identification:Auditor & + & 0.083 & 0.485 \\
$\quad$ negotiation self-efficacy & & & \\
$R^{2}$ & & 0.335 & \\
Adj. $R^{2}$ & & 0.272 & \\
F & & 6.368 & \\
Model Sig. & & 0.000 & \\
\end{tabular}

$* p<0.1, * * p<0.05, * * * p<0.01$. Two-tailed tests except for auditor negotiation self-efficacy due to the directional expectation in H1. Variables: "Client acquiescence" measures the extent to which an auditor is lenient towards the client-preferred treatment. "Auditor negotiation self-efficacy" is a variable describing the auditor's perceived ability to negotiate discretionary accounting issues with client management. "Client identification" is the extent to which an auditor identifies with a client. "Professional identification" is the extent to which the auditor identifies with the audit profession. "Client importance" is the perceived financial importance of the client to the auditor's firm. "Experience" is the number of years the auditor has worked as an auditor. "Auditor tenure" is the length of time in years the auditor has audited his or her largest client. "Big 4" is a dichotomous variable $(1=\operatorname{Big} 4$ firm, $0=$ other audit firm). "Client size" is the natural logarithm of the largest client's annual turnover in SEK. Professional identification - Auditor negotiation self-efficacy $=$ the interaction between perceived negotiation self-efficacy and auditor objectivity moderated by professional identity.

objectivity and that auditors' accuracy motive moderates the impact of auditor negotiation self-efficacy on auditor objectivity. The empirical evidence that auditors who possess higher levels of negotiation selfefficacy are more objective than are auditors with lower levels has implications for regulators, standard setters, and auditors.

First, our finding that auditors' self-efficacy beliefs affect their objectivity extends the accounting literature because previous studies of objectivity threats have focused on the existence of motives while not addressing other cognitive processes that link motivation to action. In particular, research using archival data to investigate the impact of financial incentives on auditor objectivity assumes that motivation is automatically translated into action. Research demonstrates that selfefficacy is a catalyst in the conversion of motivation into action. This means that an act with low motivation combined with high self-efficacy may be more likely than an act with high motivation and low self-efficacy due to the interaction of these factors.

Although our theoretical discussion suggests a stronger impact of auditor negotiation self-efficacy on auditor objectivity when the accuracy motive is weak or moderate than when the accuracy motive is strong, we do not find an interaction effect between the accuracy motive and perceived negotiation self-efficacy. There are two possible explanations why we could not find such an interaction effect. One possibility is that an interaction effect does not exist, and that auditors choose action options independent of their motivation for the accuracy motive. In light of our theoretical argumentation, however, this explanation is counterintuitive. In our view, the lack of variation in professional-identity strength and/or professional-identity salience appears to be a more likely explanation. The measure of professional identification does not vary enough between the sampled auditors with stronger versus weaker professional identities. The studied auditors are all very experienced and therefore tend to have strong professional identities. In addition, it is possible that in the test situation, professional identity is not sufficiently salient. Bauer (2014) reported that the salience of auditor professional identification is of great importance to auditor assessments.

Second, our main finding contributes to the accounting literature concerning methods for enhancing auditor objectivity, which identifies auditor rotation, making auditors aware of objectivity threats, and increasing the salience of professional identity as such methods. Rotation has been criticized in the literature for degrading audit quality and for the costs associated with repeatedly replacing the auditor. Researchers claim that the costs of rotation are higher than the gains, or alternatively that there are no objectivity gains associated with rotation (Gul, Fung, \& Jaggi, 2009; Kwon, Lim, \& Simnett, 2014; Myers, Myers, \& Omer, 2003; Said \& Khasharmeh, 2014). Other methods requiring auditors to be aware of situations that threaten objectivity (e.g., longevity of auditor engagement, or magnitude of fees generated from a single audit) and to take appropriate action - even stepping down from the audit assignment - are problematic because awareness cannot be guaranteed. Notably, threats to objectivity subconsciously bias an auditor's cognition (Cianci \& Bierstaker, 2009; Svanberg \& Öhman, 2015). Ensuring a high level of negotiation self-efficacy among auditors is a way to reinforce auditor objectivity that could be effective against subconscious threats. Moreover, unlike auditor rotation, ensuring high negotiation self-efficacy could counteract short-tenure objectivity threats. Both financial incentives and client identification can be considered such threats (Bauer, 2014), and Svanberg et al. (2017) argue that leadership exerted by client management can also be rapidly developed.

The fact that negotiation self-efficacy can be systematically developed (Bandura, 1997) further adds to its usefulness. Audit firms can increase domain-level auditor negotiation self-efficacy through appropriate recruitment and/or training (cf. Miles \& Maurer, 2012; Sullivan et al., 2006). The literature claims that leadership helps build follower self-efficacy by expressing confidence, developing follower potential, and emphasizing the relationship between persistence and important goals and values (e.g., Conger \& Kanungo, 1987; Shamir et al., 1993; van Knippenberg et al., 2004). Auditor negotiation self-efficacy therefore appears to be affected by leadership, meaning that it can be increased in order to strengthen auditor objectivity.

Like any other research, this study has a number of limitations, including the modest response rate and potential non-response bias, social-desirability bias, the measurement of auditors' client acquiescence using a constructed scenario, our measure of client importance, and the long average tenure of the auditors in the study. Due to the fact that we used a sample of experienced Swedish auditors and because Swedish law does not constrain tenure in the same way as many other countries, our sample average tenure is eight years. This time frame is longer than would be obtained in a sample from a country limiting auditor tenure more rigorously (e.g., the United States). Although we control for auditor tenure in our analysis and there is no conclusive evidence of a negative impact of tenure on audit quality in the accounting literature, it is possible that our sample of long tenure audits limits the generalizability of our result. Our measure of client importance was insignificant in the regression model, suggesting that possible future research in client importance may need to be measured at the partner level or office level rather than firm level, depending on firm structure and partner compensation scheme. These limitations indicate that the results should be interpreted cautiously. We also note that our measure of professional identification is not an ideal proxy for auditors' accuracy motive, limiting our test of the interaction between negotiation self-efficacy and auditors' accuracy motive. Nevertheless, since the study provides empirical evidence that auditors' negotiation self-efficacy is related to auditor objectivity, future research could continue to explore how various forms of self-concept-related constructs affect auditor objectivity. Future research might consider a 
longitudinal study, which would be particularly suited for this task.

Since self-efficacy does not correspond to knowledge or actual negotiation capacity, it would be of interest for future research to examine the extent to which auditor negotiation self-efficacy can be enhanced. We suggest that negotiation self-efficacy offers a potential short cut to improving auditor objectivity because it may be easier to improve selfefficacy than it is to develop real negotiation skills. The literature argues that self-efficacy can be enhanced through several methods (cf. Bandura, 1997), e.g., recruitment and training (Miles \& Maurer, 2012; Sullivan et al., 2006) and leaders' role modelling (Conger \& Kanungo, 1987; Shamir et al., 1993; van Knippenberg et al., 2004). A study of a closely related social-psychological phenomenon that offers inspiration for how to address these issues is Bauer (2014). It finds that professional-identity salience can be aroused by psychological priming, which is a situation-specific temporary heightening of the impact of professional identity on behaviour that is accomplished with very simple means and no cost, e.g. looking at a document issued by an accounting organization, an image of a professional role model, etc. Bauer's (2014) findings demonstrate how one aspect of the self-concept, a social identity, can be made an effective regulator of auditor objectivity. Psychological theory (Leary and Tangney, 2003) claims that several constructs are closely related, e.g. self-esteem, self-efficacy, and particular (social) identities, suggesting that auditor negotiation self-efficacy may be associated with professional identity strength and salience. Bauer (2014) finds that professional identity has its strongest effects on auditor objectivity if it is made salient, suggesting that future research could investigate whether arousing professional identity is a way to trigger auditors' negotiation self-efficacy due to a link between social identity and self-efficacy.

\section{Financial support}

The researchers wish to thank Handelsbankens Forskningsstiftelser for their financial support of this project.

\section{Appendix A. Appendix}

\section{A.1. Measures used in the study}

\section{A.1.1. Domain-level auditor negotiation self-efficacy}

Think of negotiation situations in general, not of any one specific negotiation and not of any particular client. Please assess the statements below indicating your response between 1 (do not agree at all) and 10 (totally agree).

In a negotiation about a material accounting issue with clients, I am good at convincing the client to agree with me.

I am skilled at preventing the client from exploiting my weaknesses in a negotiation about a material accounting issue with the client.

I am good at gaining the upper hand in a negotiation about a material accounting issue with my client.

I am good at persuading my client to make most of the concessions in a negotiation about a material accounting issue.

In a negotiation with my client about a material accounting issue, I am skilled at finding tradeoffs that benefit both parties.

In a negotiation with my client about a material accounting issue, I am skilled at exchanging concessions.

In a negotiation with my client about a material accounting issue, I am good at looking for an agreement that maximizes the gains of both sides.

When negotiating about a material accounting issue with my client, I am skilled at establishing a high level of rapport with my client.

\section{A.1.2. Auditor's client acquiescence}

Please respond to the following short audit case. We appreciate that you would normally require more information. However, for the purpose of our study, we ask that you respond (1) based on the limited information provided and (2) assuming that the case involves your largest client referred to above. Please indicate your response as a likelihood between 10 (very low likelihood) and 1 (very high likelihood).

In the current year's audit, a dispute has arisen between you and the management of your largest client over the materiality of certain unrecorded liabilities discovered by you during the audit. Professional and firm guidelines do not provide a definitive answer on the materiality of the amount involved. In your opinion, the amount is material. However, the client management strongly disagrees. The client's CFO argues that the total amount of unrecorded liabilities is immaterial and, therefore, that it is unnecessary to make adjusting entries in the financial statements. As the auditor, how likely is it that you will not require these liabilities to be recorded?

\section{A.1.3. Client identification}

Apply the following statements to your largest client. Please indicate your responses between 1 (do not agree at all) and 10 (totally agree).

When someone praises this client, it feels like a personal compliment.

When I talk about this client, I usually say "we" rather than "they". This client's successes are my successes.

When someone criticizes this client, it feels like a personal insult.

\section{A.1.4. Professional identification}

Apply the following statements to the audit profession. Please indicate your responses between 1 (do not agree at all) and 10 (totally agree).

When someone criticizes my profession, it feels like a personal insult.

When I talk about my profession, I usually say "we" rather than "they".

I am very interested in what others think about my profession.

My profession's successes are my successes.

When someone praises my profession, it feels like a personal compliment.

\section{A.1.5. Client importance}

Please estimate the financial importance of your largest client to your firm. Apply the following statements to your largest client. Please indicate your response as follows: $1=$ not at all important, $2=$ slightly important, $3=$ considerably important, and $4=$ very important.

\section{References}

Ahmad, Z., Ismail, H., \& Anantharaman, R. N. (2015). To be or not to be: An investigation of accounting students' career intentions. Education + Training, 57(3), 360-376.

Antle, R., \& Nalebuff, B. (1991). Conservatism and auditor-client negotiations. Journal of Accounting Research, 31-54.

Armstrong, J. S., \& Overton, T. S. (1977). Estimating nonresponse bias in mail surveys. Journal of Marketing Research, 396-402.

Ashbaugh, H. (2004). Ethical issues related to the provision of audit and non-audit services: Evidence from academic research. Journal of Business Ethics, 52(2), 143-148.

Bamber, E. M., \& Iyer, V. M. (2007). Auditors' identification with their clients and its effect on auditors' objectivity. Auditing: A Journal of Practice \& Theory, 26(2), 1-24.

Bame-Aldred, C. W., \& Kida, T. (2007). A comparison of auditor and client initial negotiation positions and tactics. Accounting, Organizations and Society, 32(6), 497-511.

Bandura, A. (1977). Self-efficacy: Toward a unifying theory of behavioral change. Psychological Review, 84(2), 191.

Bandura, A. (1982). Self-efficacy mechanism in human agency. American Psychologist, 37(2), 122.

Bandura, A. (1997). Self-efficacy: The exercise of control. Macmillan.

Bandura, A., \& Cervone, D. (1983). Self-evaluative and self-efficacy mechanisms governing the motivational effects of goal systems. Journal of Personality and Social Psychology, 45(5), 1017.

Bauer, T. D. (2014). The effects of client identity strength and professional identity salience on auditor judgments. The Accounting Review, 90(1), 95-114.

Beattie, V., Fearnley, S., \& Brandt, R. (2001). Behind closed doors. New York, NY: Palgrave.

Bedard, J. C., \& Johnstone, K. M. (2004). Earnings manipulation risk, corporate governance risk, and auditors' planning and pricing decisions. The Accounting Review, 79(2), 277-304.

Bouffard-Bouchard, T. (1990). Influence of self-efficacy on performance in a cognitive task. The Journal of Social Psychology, 130(3), 353-363. 
Brandon, D. M., Crabtree, A. D., \& Maher, J. J. (2004). Nonaudit fees, auditor independence, and bond ratings. Auditing: A Journal of Practice \& Theory, 23(2), 89-103.

Brett, J. F., Pinkley, R. L., \& Jackofsky, E. F. (1996). Alternatives to having a BATNA in dyadic negotiation: The influence of goals, self-efficacy, and alternatives on negotiated outcomes. International Journal of Conflict Management, 7(2), 121-138.

Callaghan, J., Parkash, M., \& Singhal, R. (2009). Going-concern audit opinions and the provision of nonaudit services: Implications for auditor independence of bankrupt firms. Auditing: A Journal of Practice \& Theory, 28(1), 153-169.

Caprara, G. V., Barbaranelli, C., Steca, P., \& Malone, P. S. (2006). Teachers' self-efficacy beliefs as determinants of job satisfaction and students' academic achievement: A study at the school level. Journal of School Psychology, 44(6), 473-490.

Carey, P., \& Simnett, R. (2006). Audit partner tenure and audit quality. The Accounting Review, 81(3), 653-676.

Carrington, T., Johansson, T., Johed, G., \& Öhman, P. (2013). An empirical test of the hierarchical construct of professionalism and managerialism in the accounting profession. Behavioral Research in Accounting, 25(2), 1-20.

Cerasoli, C. P., Nicklin, J. M., \& Ford, M. T. (2014). Intrinsic motivation and extrinsic incentives jointly predict performance: A 40-year meta-analysis. Psychological Bulletin, 140(4), 980.

Chen, G., \& Bliese, P. D. (2002). The role of different levels of leadership in predicting self-and collective efficacy: Evidence for discontinuity. Journal of Applied Psychology, 87(3), 549.

Chen, G., Gully, S. M., \& Eden, D. (2001). Validation of a new general self-efficacy scale. Organizational Research Methods, 4(1), 62-83.

Chen, J. A., \& Tutwiler, M. S. (2017). Implicit theories of ability and self-efficacy. Zeitschrift für Psychologie, 225, 127-136.

Cianci, A. M., \& Bierstaker, J. (2009). Auditors' efficiency motivated evaluation. Advances in Accounting, 25(1), 20-27.

Conger, J. A., \& Kanungo, R. N. (1987). Toward a behavioral theory of charismatic leadership in organizational settings. Academy of Management Review, 12(4), 637-647.

Craswell, A., Stokes, D. J., \& Laughton, J. (2002). Auditor independence and fee dependence. Journal of Accounting and Economics, 33(2), 253-275.

Dart, E. (2011). UK investors' perceptions of auditor independence. The British Accounting Review, 43(3), 173-185.

Deangelo, L. E. (1981). Auditor independence, 'low balling', and disclosure regulation. Journal of Accounting and Economics, 3(2), 113-127.

Defond, M. L., Raghunandan, K., \& Subramanyam, K. R. (2002). Do non-audit service fees impair auditor independence? Evidence from going concern audit opinions. Journal of Accounting Research, 40(4), 1247-1274.

Deis, D. R., Jr., \& Giroux, G. A. (1992). Determinants of audit quality in the public sector. Accounting Review, 462-479.

Dykxhoorn, H. J., \& Sinning, K. E. (1982). Perceptions of auditor independence: Its perceived effect on the loan and investment decisions of German financial statement users. Accounting, Organizations and Society, 7(4), 337-347.

Francis, J. R. (2006). Are auditors compromised by nonaudit services? Assessing the evidence. Contemporary Accounting Research, 23(3), 747-760.

Francis, J. R., \& Ke, B. (2006). Disclosure of fees paid to auditors and the market valuation of earnings surprises. Review of Accounting Studies, 11(4), 495-523.

Frankel, R. M., Johnson, M. F., \& Nelson, K. K. (2002). The relation between auditors' fees for nonaudit services and earnings management. The Accounting Review, 77(s-1), 71-105.

Geiger, M. A., \& Raghunandan, K. (2002). Auditor tenure and audit reporting failures. Auditing: A Journal of Practice \& Theory, 21(1), 67-78.

Geiger, M. A., \& Rama, D. V. (2003). Audit fees, nonaudit fees, and auditor reporting on stressed companies. Auditing: A Journal of Practice \& Theory, 22(2), 53-69.

Gibbins, M., McCracken, S. A., \& Salterio, S. E. (2005). Negotiations over accounting issues: The congruency of audit partner and chief financial officer recalls. Auditing: A Journal of Practice \& Theory, 24(s-1), 171-193.

Gibbins, M., McCracken, S., \& Salterio, S. E. (2010). The auditor's strategy selection for negotiation with management: Flexibility of initial accounting position and nature of the relationship. Accounting, Organizations and Society, 35(6), 579-595.

Gibbins, M., \& Newton, J. D. (1994). An empirical exploration of complex accountability in public accounting. Journal of Accounting Research, 165-186.

Gist, M. E., Stevens, C. K., \& Bavetta, A. G. (1991). Effects of self-efficacy and posttraining intervention on the acquisition and maintenance of complex interpersonal skills. Personnel Psychology, 44(4), 837-861.

Gul, F. A. (1991). Size of audit fees and perceptions of auditors' ability to resist management pressure in audit conflict situations. Abacus, 27(2), 162-172.

Gul, F. A., Fung, S. Y. K., \& Jaggi, B. (2009). Earnings quality: Some evidence on the role of auditor tenure and auditors' industry expertise. Journal of Accounting and Economics, 47(3), 265-287.

Hackenbrack, K., \& Nelson, M. W. (1996). Auditors' incentives and their application of financial accounting standards. Accounting Review, 43-59.

Hellman, N. (2011). Chief financial officer influence on audit planning. International Journal of Auditing, 15(3), 247-274.

Hillison, S. M., \& Peecher, M. E. (2017). Discussion of "The Consequences of AuditRelated Earnings Revisions". Contemporary Accounting Research, 34(4), 1915-1921.

Hollingsworth, C., \& Li, C. (2012). Investors' perceptions of auditors' economic dependence on the client: Post-SOX evidence. Journal of Accounting, Auditing \& Finance, 27(1), 100-122.

Hwang, P. C., Han, M. C., \& Chiu, S. F. (2015). Role breadth self-efficacy and foci of proactive behavior: Moderating role of collective, relational, and individual selfconcept. The Journal of Psychology, 149(8), 846-865.

Iskandar, T., Nelly-Sari, R., Mohd-Sanusi, Z., \& Anugerah, R. (2012). Enhancing auditors' performance: The importance of motivational factors and the mediation effect of effort. Managerial Auditing Journal, 27(5), 462-476.

Jungert, T., Koestner, R. F., Houlfort, N., \& Schattke, K. (2013). Distinguishing source of autonomy support in relation to workers' motivation and self-efficacy. The Journal of Social Psychology, 153(6), 651-666.

Kadous, K., Kennedy, S. J., \& Peecher, M. E. (2003). The effect of quality assessment and directional goal commitment on auditors' acceptance of client-preferred accounting methods. The Accounting Review, 78(3), 759-778.

Kaplan, S. E., O'Donnell, E. F., \& Arel, B. M. (2008). The influence of auditor experience on the persuasiveness of information provided by management. Auditing: A Journal of Practice \& Theory, 27(1), 67-83.

Keune, M. B., \& Johnstone, K. M. (2012). Materiality judgments and the resolution of detected misstatements: The role of managers, auditors, and audit committees. The Accounting Review, 87(5), 1641-1677.

Klayman, J., \& Ha, Y. W. (1989). Hypothesis testing in rule discovery: Strategy, structure, and content. Journal of Experimental Psychology: Learning, Memory, and Cognition, 15(4), 596.

Knechel, W. R., \& Vanstraelen, A. (2007). The relationship between auditor tenure and audit quality implied by going concern opinions. Auditing: A Journal of Practice \& Theory, 26(1), 113-131.

Krishnan, J., Sami, H., \& Zhang, Y. (2005). Does the provision of nonaudit services affect investor perceptions of auditor independence? Auditing: A Journal of Practice \& Theory, 24(2), 111-135.

Kunda, Z. (1990). The case for motivated reasoning. Psychological Bulletin, 108(3), 480.

Kwon, S. Y., Lim, Y., \& Simnett, R. (2014). The effect of mandatory audit firm rotation on audit quality and audit fees: Empirical evidence from the Korean audit market. Auditing: A Journal of Practice \& Theory, 33(4), 167-196.

Larcker, D. F., \& Richardson, S. A. (2004). Fees paid to audit firms, accrual choices, and corporate governance. Journal of Accounting Research, 42(3), 625-658.

Lavin, D. (1977). Some effects of the perceived independence of the auditor. Accounting, Organizations and Society, 2(3), 237-244.

Lax, D., \& Sebenius (2011). Manager as negotiator. Free Press.

Leary, M. R., \& Tangney, J. P. (2003). The self as an organizing construct in the behavioral and social sciences. Handbook of Self and Identity, 3-14.

Leboeuf, R. A., Shafir, E., \& Bayuk, J. B. (2010). The conflicting choices of alternating selves. Organizational Behavior and Human Decision Processes, 111(1), 48-61.

Lee, C., \& Bobko, P. (1994). Self-efficacy beliefs: Comparison of five measures. Journal of Applied Psychology, 79(3), 364.

Libby, R., \& Luft, J. (1993). Determinants of judgment performance in accounting settings: Ability, knowledge, motivation, and environment. Accounting, Organizations and Society, 18(5), 425-450.

Locke, E. A., Frederick, E., Lee, C., \& Bobko, P. (1984). Effect of self-efficacy, goals, and task strategies on task performance. Journal of Applied Psychology, 69(2), 241.

Locke, E. A., \& Latham, G. P. (1990). A theory of goal setting \& task performance. PrenticeHall Inc.

Lohman, M. C. (2006). Factors influencing teachers' engagement in informal learning activities. Journal of Workplace Learning, 18(3), 141-156.

Mael, F., \& Ashforth, B. E. (1992). Alumni and their alma mater: A partial test of the reformulated model of organizational identification. Journal of Organizational Behavior, 13(2), 103-123.

Mayhew, B. W., Schatzberg, J. W., \& Sevcik, G. R. (2001). The effect of accounting uncertainty and auditor reputation on auditor objectivity. Auditing: A Journal of Practice \& Theory, 20(2), 49-70.

McCracken, S., Salterio, S. E., \& Gibbins, M. (2008). Auditor-client management relationships and roles in negotiating financial reporting. Accounting, Organizations and Society, 33(4-5), 362-383.

Merchant, K. A. (2006). Measuring general managers' performances: Market, accounting and combination-of-measures systems. Accounting, Auditing \& Accountability Journal, 19(6), 893-917.

Miceli, M. P., \& Near, J. P. (1992). Blowing the whistle: The organizational and legal implications for companies and employees. Lexington Books.

Midgley, C., Feldlaufer, H., \& Eccles, J. S. (1989). Change in teacher efficacy and student self-and task-related beliefs in mathematics during the transition to junior high school. Journal of Educational Psychology, 81(2), 247.

Miles, E. W., \& Lasalle, M. M. (2008). Asymmetrical contextual ambiguity, negotiation self-efficacy, and negotiation performance. International Journal of Conflict Management, 19(1), 36-56.

Miles, E. W., \& Maurer, T. J. (2012). Advancing validity of self-efficacy in negotiation through focusing at the domain level. Journal of Occupational and Organizational Psychology, 85(1), 23-41.

Myers, J. N., Myers, L. A., \& Omer, T. C. (2003). Exploring the term of the auditor-client relationship and the quality of earnings: A case for mandatory auditor rotation? The Accounting Review, 78(3), 779-799.

Nelson, M. W., Elliott, J. A., \& Tarpley, R. L. (2002). Evidence from auditors about managers' and auditors' earnings management decisions. The Accounting Review, 77(s1), 175-202.

Patel, V. L., \& Groen, G. J. (1986). Knowledge based solution strategies in medical reasoning. Cognitive Science, 10(1), 91-116.

Perreault, S., \& Kida, T. (2011). The relative effectiveness of persuasion tactics in auditor-client negotiations. Accounting, Organizations and Society, 36(8), 534-547.

Perreault, S., Kida, T., \& David Piercey, M. (2017). The relative effectiveness of simultaneous versus sequential negotiation strategies in auditor-client negotiations. Contemporary Accounting Research, 34(2), 1048-1070.

Phillips, J. M., \& Gully, S. M. (1997). Role of goal orientation, ability, need for achievement, and locus of control in the self-efficacy and goal-Setting process. Journal of Applied Psychology, 82(5), 792.

Reynolds, J. K., \& Francis, J. R. (2000). Does size matter? The influence of large clients on 
office-level auditor reporting decisions. Journal of Accounting and Economics, 30(3), 375-400.

Said, K. M., \& Khasharmeh, H. A. (2014). Mandatory audit firm rotation and audit costs: A survey of auditing firms in Bahrain. Journal of Finance and Accounting, 2(6), 116-128.

Sanchez, M. H., Agoglia, C. P., \& Hatfield, R. C. (2007). The effect of auditors' use of a reciprocity-based strategy on auditor-client negotiations. The Accounting Review, 82(1), 241-263.

Schleifer, L. L., \& Dull, R. B. (2009). Metacognition and performance in the accounting classroom. Issues in Accounting Education, 24(3), 339-367.

Shamir, B., House, R. J., \& Arthur, M. B. (1993). The motivational effects of charismatic leadership: A self-concept based theory. Organization Science, 4(4), 577-594.

Shockley, R. A. (1981). Perceptions of auditors' independence: An empirical analysis. Accounting Review, 785-800.

Simunic, D. A. (1984). Auditing, consulting, and auditor independence. Journal of Accounting Research, 679-702.

Srinidhi, B. N., \& Gul, F. A. (2007). The differential effects of auditors' nonaudit and audit fees on accrual quality. Contemporary Accounting Research, 24(2), 595-629.

Stajkovic, A. D., \& Luthans, F. (1998). Self-efficacy and work-related performance: A meta-analysis. Psychological Bulletin, 124(2), 240.

Stefaniak, C. M., Houston, R. W., \& Cornell, R. M. (2012). The effects of employer and client identification on internal and external auditors' evaluations of internal control deficiencies. Auditing: A Journal of Practice \& Theory, 31(1), 39-56.

Stevens, C. K. \& Gist, M. E. (1997). Effects of self-efficacy and goal-orientation training on negotiation skill maintenance: What are the mechanisms? Personnel Psychology, 50(4), 955-978.

Suddaby, R., Gendron, Y., \& Lam, H. (2009). The organizational context of professionalism in accounting. Accounting, Organizations and Society, 34(3-4), 409-427.

Sullivan, B. A., O'Connor, K. M., \& Burris, E. R. (2006). Negotiator confidence: The impact of self-efficacy on tactics and outcomes. Journal of Experimental Social Psychology, $42(5), 567-581$.

Svanberg, J., \& Öhman, P. (2015). Auditors' identification with their clients: Effects on audit quality. The British Accounting Review, 47(4), 395-408.

Svanberg, J., \& Öhman, P. (2016). Does Charismatic Client Leadership Constrain Auditor Objectivity? Behavioral Research in Accounting, 29(1), 103-118.

Svanberg, J., Öhman, P., \& Neidermeyer, P. E. (2017). The relationship between transformational client leadership and auditor objectivity. Accounting, Auditing \& Accountability Journal, 30(5), 1142-1159.

Svanberg, J., Öhman, P., \& Neidermeyer, P. E. (2018). Client-identified auditor's initial negotiation tactics: A social-identity perspective. Managerial Auditing Journal. https:// doi.org/10.1108/MAJ-10-2016-1467.

Sweeney, B., \& Pierce, B. (2011). Audit team defence mechanisms: Auditee influence. Accounting and Business Research, 41(4), 333-356.

Trotman, K. T., Wright, A. M., \& Wright, S. (2005). Auditor negotiations: An examination of the efficacy of intervention methods. The Accounting Review, 80(1), 349-367.

Tschannen-Moran, M., Hoy, A. W., \& Hoy, W. K. (1998). Teacher efficacy: Its meaning and measure. Review of Educational Research, 68(2), 202-248.

Van Knippenberg, D., Van Knippenberg, B., De Cremer, D., \& Hogg, M. A. (2004) Leadership, self, and identity: A review and research agenda. The Leadership Quarterly, 15(6), 825-856.

Wang, G., \& Netemeyer, R. G. (2002). The effects of job autonomy, customer demandingness, and trait competitiveness on salesperson learning, self-efficacy, and performance. Journal of the Academy of Marketing Science, 30(3), 217-228.

Wan-Huggins, V. N., Riordan, C. M., \& Griffeth, R. W. (1998). The development and longitudinal test of a model of organizational identification. Journal of Applied Social Psychology, 28(8), 724-749.

Weil, J., \& Tannenbaum, J. (2001). Big companies pay audit firms more for other services. Wall Street Journal, 10.

Wright, A., \& Wright, S. (1997). An examination of factors affecting the decision to waive audit adjustments. Journal of Accounting, Auditing \& Finance, 12(1), 15-36.

Youssef, C. M., \& Luthans, F. (2005). A positive organizational behavior approach to ethical performance. Positive Psychology in Business Ethics and Corporate Responsibility, $1-22$.

Jan Svanberg is Assistant Professor (Ph.D.) of business administration at the University of Gavel. His research interests are behavioural issues, primary in accounting and auditing.

Peter Öhman is Professor (Ph.D.) of business administration at Centre for Research on Economic Relations (CER) at Mid Sweden University. His research interests are primary in accounting, auditing and banking.

Presha E. Neidermeyer, Ph.D., CPA is a Professor of Accounting at West Virginia University. Her primary research interests are in international auditor behaviour and gender issues. 